\title{
Állásfoglalás az egészségügyi dolgozók hepatitis B-vírus-fertőzéssel szembeni immunizációjáról*
}

\author{
Jekkel Csilla dr. ${ }^{1}$ - Onozó Beáta dr. ${ }^{2}$ \\ Scharek Petra dr. ${ }^{3}$. Kulcsár Andrea dr. ${ }^{1}$ \\ ${ }^{1}$ Dél-pesti Centrumkórház, Országos Hematológiai és Infektológiai Intézet, Budapest \\ ${ }^{2}$ Borsod-Abaúj-Zemplén Megyei Központi Kórház és Egyetemi Oktatókórház, \\ Gyermekegészségügyi Központ, Miskolc \\ ${ }^{3}$ Magyar Honvédség Egészségügyi Központ, I. Belgyógyászati Osztály, Budapest
}

\begin{abstract}
Világszerte több mint 200 millió, a hepatitis B-vírus felületi antigénre (HBsAg-) pozitív, hepatitis B-vírus (HBV)hordozó él. Az egészségügyi dolgozók a munkájuk miatt fokozottan ki vannak téve a hepatitis B-fertőzés veszélyének. A fertőzés elkerülésére hatékony védőoltás áll rendelkezésünkre, de sajnos az oltás után bizonyos tényezőktőll függően eltérő arányban alakul ki védettség. A rizikónak kitett egészségügyi dolgozóknál ezért az oltottság mellett a védettség ellenőrzése (anti-HBs) is rendkívül fontos. A védőoltásra nonreszpondereket érdemes megpróbálni védetté tenni további alternatív oltási sorokkal. Javaslatunk végén az egészségügyi dolgozók posztexpozíciós profilaxisát is tárgyaljuk a HBV-fertőzés tekintetében. Korábban magyar nyelvű javaslat a jelen témában nem állt rendelkezésre. Orv Hetil. 2019; 160(41): 1607-1616.
\end{abstract}

Kulcsszavak: hepatitis B-vírus, védőoltás, egészségügyi dolgozó, immunizáció, posztexpozíciós profilaxis

\section{Hungarian recommendation for the immunization of health-care personnel against hepatitis $B$ virus}

\begin{abstract}
More than 200 million HBV surface antigen ( $\mathrm{HBsAg}$ ) positive, hepatitis B virus (HBV) carriers live worldwide. Health-care personnel have increasing risk for aquiring the HBV infection. An effective vaccine is available against the infection, however, a certain proportion of the vaccinated patients do not respond to the vaccine depending on certain factors. Therefore, vaccine-induced immunity (anti-HBs) should be tested at health-care workers. For nonresponders, there are other vaccination strategies to try to achieve protection. This recommendation also provides a guidance for postexposure prophylaxis following occupational exposures against HBV infection. This is the first Hungarian recommendation about this topic.
\end{abstract}

Keywords: hepatitis B virus, vaccination, health-care personnel, postexposure prophylaxis

Jekkel Cs, Onozó B, Scharek P, Kulcsár A. [Hungarian recommendation for the immunization of health-care personnel against hepatitis B virus]. Orv Hetil. 2019; 160(41): 1607-1616.

(Beérkezett: 2019. június 10.; elfogadva: 2019. július 2.)

\section{Rövidítések}

AIDS = (acquired immunodeficiency syndrome) szerzett immunhiányos tünetegyüttes; anti-HBcIgG = (antibody to hepatitis $B$ core antigen immunoglobulin class $G$ ) a hepatitis B-ví- rus „core” antigénje ellen termelt, immunglobulin-G-típusú ellenanyag; anti-HBs = (antibody to hepatitis B surface antigen) a hepatitis B-vírus felületi antigénje ellen termelt ellenanyag; $\operatorname{cccDNA}=($ covalently closed circular DNA $)$ kovalens

\footnotetext{
*A Magyar Infektológiai és Klinikai Mikrobiológiai Társaság Vezetőségének és a Magyar Gasztroenterológiai Társaság Hepatológiai Szekciója Vezetőségének szakmai egyetértésével.
} 
kötésű cirkuláris DNS; CpG = (cytidine-phosphate-guanosine) citidin-foszfát-guanozin; CpG-ODN = (cytidine-phosphateguanosine oligodeoxynucleotide) citidin-foszfát-guanozin oligodezoxinukleotid; DNS = dezoxiribonukleinsav; GSK = GlaxoSmithKline - multinacionális gyógyszeripari vállalat, Egyesült Királyság; HAV = hepatitis A-vírus; HBIG = (hepatitis $\mathrm{B}$ immune globulin) hepatitis B elleni immunglobulin; HBsAg = (hepatitis $\mathrm{B}$ surface antigen) hepatitis $\mathrm{B}$ felületi antigén; $\mathrm{HBV}=$ hepatitis $\mathrm{B}$-vírus; $\mathrm{HCC}=$ hepatocellularis carcinoma; $\mathrm{HCV}=$ hepatitis $\mathrm{C}$-vírus; HDV = hepatitis D-vírus; HIV = (human immunodeficiency virus) humán immundeficiencia vírus; IU = (international unit) nemzetközi egység; WHO = (World Health Organization) Egészségügyi Világszervezet

Magyarországon a jelenlegi javaslatot megelőzően az egészségügyi dolgozók hepatitis B-vírus (HBV) elleni immunizációja tekintetében nem állt rendelkezésre a nemzetközi irányelvekkel összhangban lévő módszertani levél, jogszabály. A jelenlegi magyar módszertani levél a HBV tekintetében a rizikócsoportba tartozóknál - például egészségügyi dolgozóknál, az egészségügyi képesítést adó közép- és felsőfokú oktatási intézményekben beiskolázott személyeknél - csak a HBV elleni védőoltás meglétét írta elő, a védettség, azaz az anti-HBs ellenőrzését nem. A nemzetközi irányelvektól való eltérések, illetve a sajnálatos tapasztalatok, azaz az egészségügyi dolgozók körében megfigyelt HBV-fertőzések miatt született az igény arra, hogy a HBV-fertőzés megelőzésére új, a nemzetközi ajánlásokkal összhangban lévő javaslatot dolgozzunk ki.

\section{A HBV-fertőzésről és megelőzéséről általában}

\section{Epidemiológia}

\section{Epidemiológia globálisan}

Világszerte 240 millió krónikus HBsAg-pozitív HBVhordozó él. Az állapot 2013-ban több mint 686000 ember halálához járult hozzá májcirrhosist, illetve hepatocellularis carcinomát okozva. A HBV-fertőzött területek prevalenciája változó, vannak alacsony $(<2 \%)$, illetve magas $(>8 \%)$ prevalenciájú országok. Az elmúlt években sok magas prevalenciájú országban csökkent a betegség előfordulása a jobb szocioökonómiai viszonyoknak, az univerzális vakcinációnak és az elérhető hatékony gyógyszeres kezeléseknek köszönhetően [1].

\section{Epidemiológia Magyarországon}

Magyarország az alacsony prevalenciájú országok közé tartozik a HBV tekintetében: a becsült HBsAg-pozitivitás prevalenciája $0,4 \%$ körül mozog [2].

\section{$H B V$}

A hepatitis B-vírus a Hepadnaviridae családba tartozó hepatotrop DNS-vírus. A HBV egyedüli rezervoárja az ember, és csak a májban replikálódik [3].

\section{Klinikum}

Az akut és a krónikus HBV-hepatitis klinikai megjelenése változó. Az akut szak lehet tünetmentes-szubklinikus, okozhat sárgasággal járó akut, ritkán fulmináns hepatitist. A krónikus fázisban a klinikai megjelenés a tünetmentes hordozástól a májcirrhosison át a hepatocellularis carcinomáig (HCC) bármilyen formában megnyilvánulhat. Krónikus HBV-hepatitis a felnőttek kevesebb mint 5\%-ában, a gyerekek 10-25\%-ában, míg az újszülöttek 80-90\%-ában alakul ki az akut hepatitist követően. Azok a betegek, akiknél az akut HBV-hepatitist követően nem alakul ki krónikus hepatitis, feltehetően nem gyógyulnak meg teljesen, a betegek jelentős részénél évekkel később a klinikai gyógyulást követően is kimutatható a májban HBV-DNS (cccDNA = kovalens kötésú cirkuláris DNS). A klinikailag gyógyult hepatitis fellángolhat, ha a beteg jelentôs immunszuppresszió, immunmoduláló kezelés alá kerül (HIV - AIDS, kemoterápia, csontveló- és szolidszervtranszplantáció, egyéb immunszuppresszív terápia - így a szteroid- és biológiai terápia is [4]). A kezeletlen krónikus HBV-fertőzés szövődményeként májfibrosis, májcirrhosis, illetve hepatocellularis carcinoma alakulhat ki.

\section{Transzmisszió}

A HBV vérrel és testváladékokkal terjed. A HBV a környezetben, beszáradt állapotban akár 7 napig is túlél. Változó mennyiségben található az ondóban, nyálban, cervicalis váladékban, könnyben, de nincs a székletben, vizeletben, izzadságban. Fertőzési kapu lehet nem intakt bór, illetve mucosalis membránok.

Az átvitel lehetőségei:

- Vérrel, vérkészítményekkel, átültetett szervvel;

- intrapartum;

- szexuálisan.

Vérrel történő átvitel előfordulhat például tûszúrásos baleset, transzfúzió esetén, nem megfelelően sterilizált orvosi eszközökkel, átültetett szervvel vagy közös tühasználattal intravénás droghasználók között, cukorbetegek fertőzött tújével. HBV-fertőzött anya intrapartum átadhatja a vírust gyermekének. A fertőzés nemcsak szexuális kontaktussal, hanem tartósabb szoros kontaktussal is terjedhet, például nem intakt bőrrel való érintkezés során gyerekek, otthonban ápolt értelmi fogyatékos lakók között, szoros családi kontaktusban élő családtagok között.

Az átvitel jellemző módja más a különböző prevalenciájú régiók között. A magas prevalenciájú régiókban az intrapartum átvitel a leggyakoribb. A horizontális, különösen a kisgyermekkori átvitel a közepesen magas prevalenciájú régiókban a leggyakoribb. Az alacsonyabb prevalenciájú területeken a szexuális és az intravénás droghasználat miatti átvitel jellemző [4].

Rizikócsoportok a HBV-fertőzés szempontjából [5]

- Egészségügyi dolgozók

- Rizikós szexuális életet élők (HBV-fertőzött személylyel szexuális kontaktus, védekezés nélküli szexuális 
érintkezés >l partnerrel, anamnézisben egyéb szexuálisan terjedő betegség, homoszexuális férfiaknál anális szexuális érintkezés)

- HIV-fertőzöttek

- Intravénás droghasználók

- Rendszeresen vérkészítményre szorulók

- Hemodializáltak

- HCV-fertőzöttek, májbetegek egyéb okból

- Börtönben fogvatartottak és dolgozók

- Szociális intézményben ápolt értelmi fogyatékosok és gondozóik

- HBV-fertőzöttel egy háztartásban élők

- Immunsérültek

- Diabeteses betegek

- HBV-endémiás területre utazók

- Baleseti helyszínelők és egyéb rendvédelmi dolgozók

\section{$H B V$-fertōzés elleni immunizáció}

\section{HBV elleni védőoltások}

A HBV elleni immunizációhoz 1982 óta a vírus felületi antigénjét, HBsAg-t használunk. Az első generációs oltóanyagok humán plazmából kivont és tisztított HBsAg-t tartalmaztak. Később az 1980-as évek második felétől rekombináns technológiával állították elő a HBsAg-t - ez utóbbi előállítási módot használják a mai napig. Létezik HBV elleni egykomponensű oltóanyag, de kombináltan más oltóanyag-komponensekkel is van forgalomban HBV elleni védőoltás [6].

\section{A Magyarországon jelenleg forgalomban lévő védőoltások $\mathrm{HBV}$ ellen}

A jelenleg Magyarországon forgalomban lévő védőoltás HBV ellen az egykomponensü, 10 vagy $20 \mu \mathrm{g}$ HBsAg-t tartalmazó oltóanyag alumíniumadjuvánssal (Engerix 10 vagy $20 \mu \mathrm{g}$ - GSK) vagy a szintén $20 \mu \mathrm{g}$ HBsAg-t tartalmazó kombinált, HAV és HBV ellen is védelmet biztosító oltóanyag (Twinrix - GSK). Az Engerixből a hagyományos oltási sor $3 \times 20 \mu \mathrm{g}$ 0-1-6 hó időközzel. A 11 és 15 év közötti serdülőknél a két oltásból álló oltási sor (0-6 hó) hasonlóan hatékony [5]. Indokolt esetekben gyorsított oltási sor és egyéb alternatív oltási sorok használhatók.

\section{A HBV elleni védőoltás indikációja}

A WHO ajánlása szerint minden gyermeket vagy serdülőt HBV elleni immunizációban kell részesíteni [7]. Az előbbieken kívül a Rizikócsoportok a HBV-fertózés szempontjából részben leírt rizikócsoportokba tartozó felnőtteket is immunizálni kell. Magyarországon 1999-től kapnak HBV elleni védőoltást a VII. osztályos tanulók a nemzeti immunizációs program részeként [8].

A HBV elleni védőoltás hatékonyságának ellenőrzése A védőoltást követően az ellenanyag (anti-HBs) megjelenésével tudjuk ellenőrizni a védettséget a HBV-fertőzéssel szemben. Az alapoltási sort követően 1-2 hónap- pal kialakult anti-HBs > 10 IU / 1 titer jelzi az immunválasz létrejöttét, ez esetben beszélünk seroconversióról, illetve úgynevezett „reszponder” egyénekről. Az anti-HBs-titer >10 IU/1 megjelenése az oltást követően nemcsak immunogenitásra utal, hanem korrelál a klinikai védettséggel is [5]. A komplett oltási sor után az egészséges gyermekeknél 95\%-ban, az egészséges, 40 év alatti felnőtteknél 90\%-ban lesz seroconversio. A védőoltás immunogenitását bizonyos tényezők rontják: dohányzás, elhízás, életkor (>40 év), krónikus megbetegedések, veseelégtelenség, cukorbetegség, coeliakia, férfinem, genetikai faktorok, immunszuppresszió. Ezekben az esetekben a védőoltás után kialakult immunválasz elégtelen lehet. Náluk nagyobb arányban történik sikertelen immunizáció, az oltott egyén szabályos oltási sorra nem, alternatív oltási sorokra is nehezebben vagy egyáltalán nem válaszol (nonreszponder), illetve konvencionális módszerrel kimutatható immunválasza nem lesz.

A HBV elleni védőoltás eredményességét a gyermekek, illetve serdülők nemzeti immunizációs programja keretében rutinszerűen nem kell ellenőrizni a védőoltás jó immunogenitása és a fenntartott nyájvédettség miatt. A HBV-fertőzésnek nagyobb eséllyel kitett, rizikócsoportba tartozó gyermekek és felnőttek esetén az egyén védelmére törekszünk, így náluk a védőoltást követően fontos, hogy ismert legyen a védettségük, tehát az antiHBs-titert ellenörizni kell. Az anti-HBs ellenőrzése optimális esetben az oltási sor után 4-6 héttel, de legfeljebb 6 hónapon belül történik [5].

Az eredményes aktív HBV elleni oltás védelmet jelent a HDV-infekcióval szemben is.

\section{A bepatitis B-virus elleni védöoltás immunológiai háttere}

\section{A védőoltásra adott normális immunválasz - reszponderek}

Az alapimmunizálás során először primer immunválasz alakul ki, amelynek első lépéseként az oltás helyén a vírusantigént felvevő és feldolgozó antigénprezentáló sejtek a regionális nyirokcsomókban mutatják be az oltóanyag antigénjét a T-helper sejteknek, illetve a nyirokcsomó csíracentrumában a naiv B-sejteknek. Az aktivált T-helper és B-sejtek között kialakuló immunológiai kapcsolat az antigénspecifikus B-sejtek proliferációját és érését eredményezi. A csíraközpontokban lezajló, pontosan szabályozott folyamat eredményeként magas affinitású, antigénspecifikus IgG-tipusú ellenanyag termelésére képes plazmasejtek alakulnak ki. A vakcinációt követően már 2 hét múlva megjelennek a keringésben az ellenanyagok, amelyek 28 nap múlva érik el a legmagasabb koncentrációjukat. A plazmasejtek egy része hosszú életü plazmasejtté alakul, ezek a csontvelöbe vándorolva biztosítják az ellenanyag termelödését, akár éveken keresztül is. Az antigénspecifikus $B$-sejtek másik részéböl memória-B-sejtek differenciálódnak, amelyek a véráramon keresztül a lépbe és egyéb extrafollicularis szervekbe vándorolnak. A memó- 
ria-B-sejtek szelektálódása a nyirokcsomó csíraközpontjában néhány hónapot vesz igénybe, kialakulásuk alapvető feltétele a T-helper-B-sejt kapcsolat.

$\mathrm{Az}$ emlékeztető oltás során az antigént már az elsődleges immunválasz során kialakult antigénspecifikus memória-B-sejtek ismerik fel. Az antigénstimulus hatására a memória-B-sejtek néhány nap alatt ellenanyag-termeló effektorsejtekké differenciálódnak, és a magas affinitású ellenanyagok 3-5 nap alatt megjelennek a keringésben. Ez a szekunder immunválasz, vagy anamnesztikus válasz. A memória-B-sejtek aktiválódása már T-sejt-közremúködés nélkül is végbemegy, és alacsonyabb antigéndózis is elegendő az aktivációhoz. Az ezen sejtek által indított immunválasz másik fontos jellemzője a gyorsaság mellett az, hogy magasabb és hosszabb ideig perzisztáló ellenanyag-koncentráció érhető el, illetve az ellenanyagok affinitása is nagyobb, összehasonlítva a primer válasszal, mivel a memória-B-sejtek a csíraközpont-reakció során a legmagasabb affinitású B-sejtekből szelektálódnak ki.

Mai tudásunk szerint az oltóanyag-antigénre adott primer és szekunder immunválasz során képződött antigénspecifikus memória-B-sejtek és hosszú életü plazmasejtek hosszú évtizedekig kimutathatók a szervezetben [9-11].

A klinikai gyakorlatban az alapimmunizálást követően 1-6 hónappal az anti-HBs-szintet mérjük, amely antitest-neutralizáló hatású, és a védettséggel korreláló markernek tekinthető. Nemzetközi konszenzus alapján a protektivitási szint >10 IU/1. Fontos azonban kiemelni, hogy a fertőzés elleni védelemben az antigénspecifikus memória-B-sejteknek is szerepük van, bár a mindennapi gyakorlatban ezeknek a sejteknek a mennyiségét nem mérjük, viszont booster oltást követően egy hónappal az anti-HBs-ellenanyagnak a protektivitási szint fölé emelkedésével tudjuk ellenőrizni funkciójukat. Emellett a hepatitis B-vakcináció során antigénspecifikus T-sejtek is aktiválódnak, a hosszú távú védelemhez ezen sejtek is hozzájárulnak.

A fentiekböl következik, hogy az az immunkompetens oltott személy, akinél az alapimmunizálást követöen 1-6 bónappal mért anti-HBs-titer $10 \mathrm{IU} / \mathrm{l}$ feletti, védettnek tekintheto" a hepatitis B-fertözéssel szemben. Ilyen esetben a védettséget igazolandó ismételt szerológiai vizsgálatra és booster oltásra a késöbbiekben nincs szükség.

\section{A védőoltásra adott, szokásostól eltérő immunválasz} - „ál” nonreszponder és valódi nonreszponder

Ha az alapimmunizálást követően 1-6 hónapon túl az anti-HBs-titer <10 IU/1, immunológiai szempontból két különböző állapotot kell végiggondolni.

- Arról van-e szó, hogy az immunizációtól eltelt idővel, az élet előrehaladtával az anti-HBs-titer fiziológiásan csökkent, akár a konvencionális kimutathatóság alá? Ebben az esetben az alapimmunizálás során az oltóanyag-antigénre adott primer és szekunder immunválasz rendben zajlott, azonban a csontvelőben lévő hosszú életű plazmasejtek által termelt, adott pillanatban mérhető anti-HBs a protektivitási szint alatt van.
Ebben az esetben egy adag booster (teszt-) oltás hatására az antigénspecifikus memória-B-sejtek gyors aktivációja következik be. Ennek eredményeként nagy mennyiségü ellenanyag-termelő plazmasejt differenciálódik, és az anti-HBs-titer protektivitási tartományba kerül. Az egyén védettségét ilyen módon bebizonyítottuk. Ez volna az „ál” nonreszponder állapot. Hasonló immunológiai folyamat játszódik le akkor is, ha a beteg hepatitis B-vírus-expozíciónak van kitéve: ekkor a vírus felületi antigénje elegendő stimulust biztosít a memória-B-sejtek számára, hogy még az infekció inkubációs ideje alatt effektorsejtekké alakuljanak, és megakadályozzák a hepatitis B-fertőzés kialakulását (természetes booster) [11].

- Ha az oltott személy valódi nonreszponder, akkor már az alapimmunizálás során valamilyen okból (ld. később) nem alakul ki protektivitási szint feletti antiHBs-titer. Ezért akár többször ismételt oltás hatására sem tapasztalunk protektivitási szint feletti anti-HBstitert, az egyén fogékony a hepatitis B-fertőzéssel szemben.

A klinikai gyakorlatban a fentieket úgy igazolbatjuk, hogy adunk az egyénnek egy booster oltást, majd 4 béttel később ellenörizzük az anti-HBs-titert. Amennyiben ez $>10 \mathrm{IU} / \mathrm{l}$, akkor az egyén „ál” nonreszponder, a bepatitis $B$-fertôzéssel szemben védett, amennyiben a titer $<10 \mathrm{IU} / \mathrm{l}$, az egyén valódi nonveszponder lehet, a hepatitis B-fertözéssel szemben fogékony maradhat [11].

\section{Mi az oka a valódi nonreszponderállapotnak?}

A HBV elleni szabályos védőoltási sor után az egészséges gyermekeknél 95\%-ban, az egészséges, 40 év alatti felnőtteknél 90\%-ban lesz seroconversio. A védőoltás immunogenitását, azaz a seroconversio esélyét bizonyos tényezők rontják: életkor (>40 év), dohányzás, elhízás, krónikus megbetegedések, veseelégtelenség, cukorbetegség, coeliakia, HIV-fertőzés, férfinem, immunszuppresszió, genetikai faktorok. Ezekben az esetekben a védőoltás után kialakult immunválasz különböző mértékben, de nagyobb eséllyel lehet elégtelen, azaz náluk nagyobb valószínűséggel találkozunk nonreszponder egyénekkel [5].

A fenti állapotokra azért fontos gondolni, mert bizonyos esetben (például hemodializált veseelégtelen beteg) előre jelezhetik nekünk az esélyt arra, hogy a hagyományos oltási sorral nagy valószínúséggel nem fogjuk tudni védetté tenni a beteget.

Más esetben pedig pont egy HBV-oltás utáni nonreszponderállapot hívhatja fel a figyelmünket bizonyos betegségekre, állapotokra, például coeliakia esetén. Valódi nonreszponderállapot hátterében igazolódhat 'silent' vagy latens coeliakia. Teljes gluténmentes diéta tartása esetén megszúnik az oltóanyag-HBsAg és a gliadin közötti versengés a HLA-DQ2-molekulához való kötődésért, ami a primer immunválasz kialakulása során az egyik kulcslépés. A betegség kiszürése és kezelése tehát amiatt is fontos, hogy az egyént később nagyobb eséllyel tudjuk védetté tenni a HBV ellen [11]. 
A klinikai gyakorlatban tehát ha találunk egy nonreszponder egyént, akkor gondoljuk végig, hogy az állapot hátterében állhat-e a fenti klinikai okok egyike. Ha azonban egy nonreszponder egyén a HBV-fertőzés szempontjából rizikócsoportba tartozik, akkor mindenképp érdemes megpróbálni alternatív oltási sorral védetté tenni $[12,13]$.

A genetikai faktorokat a mindennapi gyakorlatban nem vizsgáljuk - ezek olyan citokin-, citokinreceptor- és Toll-szerü-receptor-polimorfizmusokat, illetve HLAhaplotípusokat takarnak, amelyek előfordulása esetén nagyobb eséllyel találkozunk nonreszponderállapottal [12].

\section{A nonreszponderstatus áttörése; az alternatív oltási sorok immunológiai háttere}

Rizikóállapotú egyénnél a nonreszponderállapot áttörésére tett kísérlet azért fontos, mert protektivitási szint alatti anti-HBs akár a meglévő antigénspecifikus memória-B-sejtek ellenére sem biztosít teljes körü védelmet a hepatitis B-fertőzéssel szemben.

Ilyen esetben alternatív oltási sorokat alkalmazhatunk. - Az intramuscularisan egy időben adott nagyobb menynyiségű antigén, több különböző antigén (hepatitis A és B kombinált oltóanyag) vagy az alapimmunizálásnál több alkalommal adott azonos mennyiségű antigén több antigénprezentáló sejtet fog aktiválni, így van esély arra, hogy keletkezik annyi plazmasejt, amennyi protektivitási szint feletti anti-HBs-t tud termelni [14].

- Az intradermális vakcináció több szinergista hatáson keresztül generál az izomba adott oltásnál nagyobb immunválaszt: a dermisben az izomszövetnél nagyságrendekkel nagyobb mennyiségben találhatók hivatásos antigénprezentáló sejtek és szöveti makrofágok, amelyek a bőr immunológiai mikrokörnyezetének köszönhetően képesek elindítani az adaptív immunválaszt. Emellett a véráramból éretlen dentritikus sejt előalakok toborzása szintén hozzájárul a megfelelő T-sejt-aktivációhoz. Harmadrészt a dermisben felszabaduló szolúbilis antigének közvetlenül és gyorsan eljutnak a nyirokutakon keresztül a környéki nyirokcsomóba, következményes gyors dentritikus sejt/T-sejt aktivációt eredményezve $[15,16]$. Nem kizárt, hogy az intradermális vakcináció a jövőben szélesebb indikációs körben lesz használatos, ma azonban még a hátrányai közé tartozik, hogy nagyobb gyakorlatot igényel, időigényesebb a kivitelezése, illetve nehéz megállapítani az optimális antigénmennyiséget és -volument. Emellett gyakoribb kellemetlen lokális mellékhatásokra számíthatunk, mint az intramuscularis oltásoknál.

\section{Új adjuvánst tartalmazó oltóanyag}

A jelenleg használt alumíniumadjuváns helyett számos alternatív adjuvánssal történtek vizsgálatok. Az egyik ígéretes lehetőség a delta-inulint tartalmazó, poliszacha- rid Advax, amely állatkísérletekben fokozta a T-helper sejtek korai aktivációját és a HBV-specifikus immunválaszt.

A másik lehetőség a CpG oligonukleotid (cytidinephosphate-guanosine oligodeoxynucleotide [CpGODN]) adjuváns, amely a prokaryota sejtekre jellemző DNS-mintázatot tartalmaz. Ez az adjuváns Toll-likereceptor-9-agonistaként a veleszületett immunrendszer sejtjeinek aktiválásán keresztül fejti ki hatását. Ettől az additív hatástól azt várják, hogy a valódi nonreszponderállapotot a jelenleg alkalmazott alternatív oltási sémáknál hatékonyabban fogja áttörni. Az új adjuvánst tartalmazó oltóanyagot az Egyesült Államokban már törzskönyvezték (Heplisav-B), de Magyarországon még nincs forgalomban $[12,17]$.

\section{Egészségügyi dolgozók rizikója}

\section{Az expozició és az átvitel esélye}

Azok az egészségügyi dolgozók, akik HBV-fertőzött beteg vérével vagy egyéb testváladékával érintkezésbe kerülhetnek, a HBV szempontjából rizikócsoportba sorolhatók. A HBV rendkívül fertőző, még látható vér nélkül is, a környezetben hét napig beszáradva is életképes marad. HBV-fertőzött vérrel vagy fertőző testváladékkal történő perkután (tûszúrással), mucosalis vagy nem intakt bőrfelületen át (például psoriasis, ekcéma, bőrsérülés) létrejött expozíció potenciális rizikó az átvitelre [18]. A WHO becslése szerint évente kb. 300000 egészségügyi dolgozónál történik tűszúrásos baleset $\mathrm{HBV}$-vel fertőzött éles eszközzel [19]. Bár a perkután expozíció a leghatékonyabb átviteli mód, az egészségügyi dolgozók HBV-fertőzéseinek kivizsgálása során az esetek legnagyobb részében a fertőzöttek nem emlékeznek tûszúrásos balesetre [18]. Tüszúrásos sérülés kapcsán a fertőzés átvitelének valószínúsége a HIV esetében $0,3 \%$, a HCV esetében 0,9-2,2\%, a HBV esetében 18-30\%. A fertőzés esélyét befolyásolja az expozíció típusa, a forrás fertőzőképessége (víruskópiaszám), illetve a sérült immunstatusa. A HBV-fertőződést a megfelelő anti-HBs-szint (>10 IU/1) megakadályozza.

\section{Vérrel terjedó fertözö betegségek prevenciója az egészségügyi dolgozók körében}

Az expozíció megelőzése az egyik legfontosabb eleme a prevenciónak a vérrel terjedő fertőző betegségek esetén. Minden egészségügyi dolgozót tájékoztatni és rendszeresen oktatni kell munkája során a rizikóra, illetve annak primer megelőzésére vérrel terjedő fertőző betegségek tekintetében. Ismerniük kell a különböző szabályokat ezzel kapcsolatban, például az általános óvintézkedéseket, a védőeszközök használatát. A megelőzés másik eleme a HBV elleni védőoltás, illetve a $\mathrm{HBV}$-vel szembeni 
1. táblázat | HBV-expozíció esetén alkalmazandó posztexpozíciós profilaxis

\begin{tabular}{|c|c|c|c|}
\hline \multirow[t]{2}{*}{ A sérült oltási statusa } & \multicolumn{3}{|c|}{ A potenciális fertóző forrás serostatusa } \\
\hline & HBsAg-pozitív & HBsAg-negatív & Ismeretlen \\
\hline Nem oltott & 1 HBIG + 3 aktív & 3 aktív & 1 HBIG + 3 aktív \\
\hline Oltott reszponder & Nincs teendő & Nincs teendő & Nincs teendő \\
\hline Oltott nonreszponder & $\begin{array}{l}2 \mathrm{HBIG} \\
\text { vagy } \\
2 \mathrm{HBIG}+3 \text { aktív }\end{array}$ & $\begin{array}{l}\text { Nincs teendő } \\
\text { vagy } \\
3 \text { aktív megkísérelhető }\end{array}$ & $\begin{array}{l}\text { Nagy rizikó: } \\
2 \text { HBIG } \\
\text { vagy } \\
2 \text { HBIG + } 3 \text { aktív }\end{array}$ \\
\hline Oltott, ismeretlen válasz & $\begin{array}{l}\text { Anti-HBs } \geq 10 \mathrm{IU} / 1 \\
\text { nincs teendó }\end{array}$ & $\begin{array}{l}\text { Anti-HBs } \geq 10 \mathrm{IU} / 1 \\
\text { nincs teendo" }\end{array}$ & $\begin{array}{l}\text { Anti-HBs } \geq 10 \mathrm{IU} / 1 \\
\text { nincs teendő }\end{array}$ \\
\hline & $\begin{array}{l}\text { Anti-HBs }<10 \mathrm{IU} / 1 \\
1 \mathrm{HBIG}+3 \text { aktív }\end{array}$ & $\begin{array}{l}\text { Anti-HBs }<10 \mathrm{IU} / 1 \\
1 \text { booster }\end{array}$ & $\begin{array}{l}\text { Anti-HBs }<10 \mathrm{IU} / 1 \\
1 \mathrm{HBIG}+3 \text { aktív }\end{array}$ \\
\hline
\end{tabular}

anti-HBs = a hepatitis B-vírus felületi antigénje ellen termelt ellenanyag; HBIG = hepatitis B elleni immunglobulin; HBsAg = hepatitis B felületi antigén

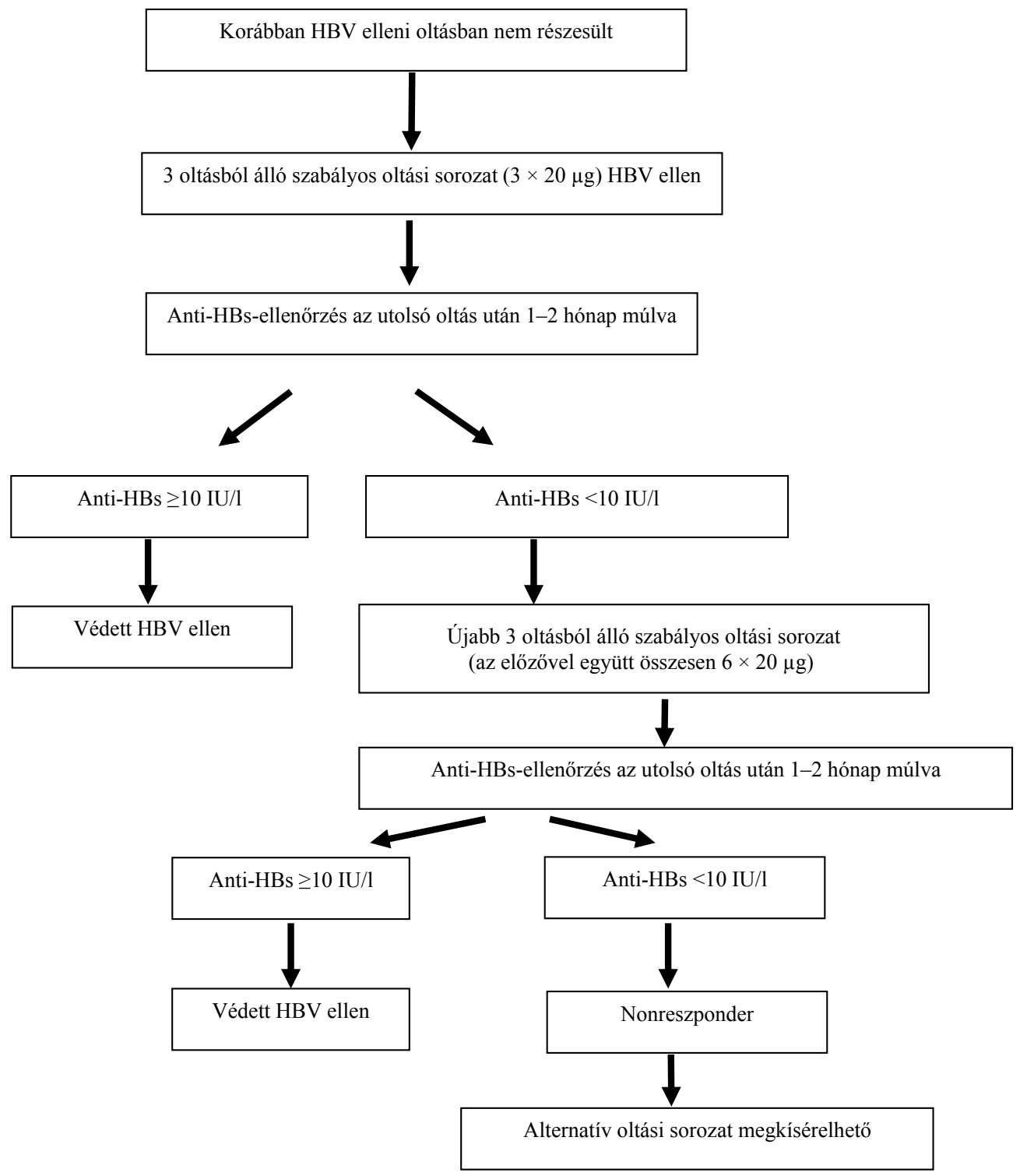

1. ábra | Korábban HBV elleni védőoltásban nem részesült egészségügyi dolgozóra vonatkozó oltási javaslat 
védettség ismerete. Ezeken kívül tudniuk kell expozíció esetén a teendőket, a posztexpozíciós profilaxis menetét $[18,20]$.

\section{A HBV elleni védelem immunizációval}

A 18/1998. (VI. 3.) NM rendelet 9. paragrafusának 1. bekezdése szerint: a munkáltató köteles a munkavállalók egészségét és biztonságát veszélyeztető munkahelyi biológiai expozíciókat a külön jogszabályban (61/1999. [XII. 1.] EüM rendelet) foglaltaknak megfelelően felmérni. A megbetegedési veszély csökkentése érdekében - a munkáltatónak a foglalkoztatás feltételeként - biztosítania kell az adott veszélyeztetett munkakörben foglalkoztatott dolgozók védőoltását [21].

A fentiek értelmében a HBV elleni védőoltás biztosítása, a védettség ellenőrzéséhez szükséges szerológiai vizsgálatok elvégzése és a posztexpozíciós profilaxishoz szükséges védőoltások (aktív és passzív immunizáció), valamint a szerológiai vizsgálatok a munkáltató, illetve az egészségügyi irányú oktatási intézmény feladata, költsége.

\section{Javaslat az egészségügyi dolgozók, egészségügyi közép-és felsőoktatási intézményben tanulók HBV elleni immunizációjára}

$\mathrm{Az}$ egészségügyi dolgozók rizikócsoportba tartoznak a HBV-fertőzés tekintetében, ezért HBV-fertőzés elleni védettségük alapvető igény. Nem elegendő a védőoltás meglétét regisztrálni, ellenőrizni és dokumentálni kell a védettségüket. Minden közép- és felsőoktatási egészségügyi intézménybe belépőnél, új egészségügyi dolgozónál ellenőrizni kell a védőoltás meglétét és az anti-HBs-titert. Amennyiben a jelentkező nem oltott, védőoltásban kell részesíteni, majd az oltást követően ellenőrizni kell a védettséget, azaz az anti-HBs-titert, és mindezt dokumentálni kell $[18,19]$.

Korábban nem oltott személy (1. ábra)

$\mathrm{Az}$ egészségügyi intézménybe belépő dolgozó, egészségügyi szakirányú közép- vagy felsőfokú oktatási intézménybe belépő tanuló, hallgató, aki korábban HBV elleni immunizációban nem részesült, szabályos oltási sémában oltandó: 3, egyenként $20 \mu \mathrm{g} \mathrm{HBsAg-t}$ tartalmazó oltóanyag 0-1-6 hó időközzel. Az oltási sor után 1-2 hónappal az anti-HBs-szintet ellenőrizni kell. Ha az anti-HBs-titer pozitív lett (>10 IU/1), az egyén védett, reszponder. (Az oltási válasz ellenőrzése a 0-1. oltás után 1-2 hónappal már elvégezhető, ha a veszélyeztetett munkakör betöltése sürgető.)

Amennyiben szabályos oltási sor után rövid idővel ellenőrizve ( 6 hónapon belül) anti-HBs-titere negatív $(<10 \mathrm{IU} / 1)$, és az anti-HBcIgG és a HBsAg is negatív, akkor az oltási sort ismételni kell, szabályos séma szerint. A megismételt szabályos oltási sor után ismételten ellenőrizni kell a védettség kialakulását. Amennyiben ezt kö- vetően sem alakult ki védettség, akkor az egyén nonreszponder [18, 19]. A nonreszpondereknél alternatív oltási sémával lehet további próbát tenni.

\section{Korábban HBV ellen oltott személy (2. ábra)}

$\mathrm{Az}$ az egészségügyi intézménybe belépő dolgozó, egészségügyi szakirányú közép- vagy felsőfokú oktatási intézménybe belépő tanuló, hallgató, aki korábban HBV elleni immunizációban részesült, és korábban, az oltást követően dokumentáltak szerint pozitív (>10 IU/1) anti-HBs-titerrel rendelkezik, védettnek tekinthető. Ép immunitásúaknál az anti-HBs-titert nem kell többet ellenőrizni, nem kell booster oltást alkalmazni. Ha az oltott személyeknél nem történt korábban, az oltást követően HBV szerológiai ellenőrzés, akkor ezt pótolni kell (anti-HBs, HBsAg, anti-HBcIgG). Amennyiben az antiHBs pozitív, >10 IU/1, akkor az egyén védett. Ha az anti-HBs-titere <10 IU/1, és emellett a HBsAg és az anti-HBcIgG is negatív, akkor két lehetőség áll fenn: lehet valódi vagy „ál” nonreszponder.

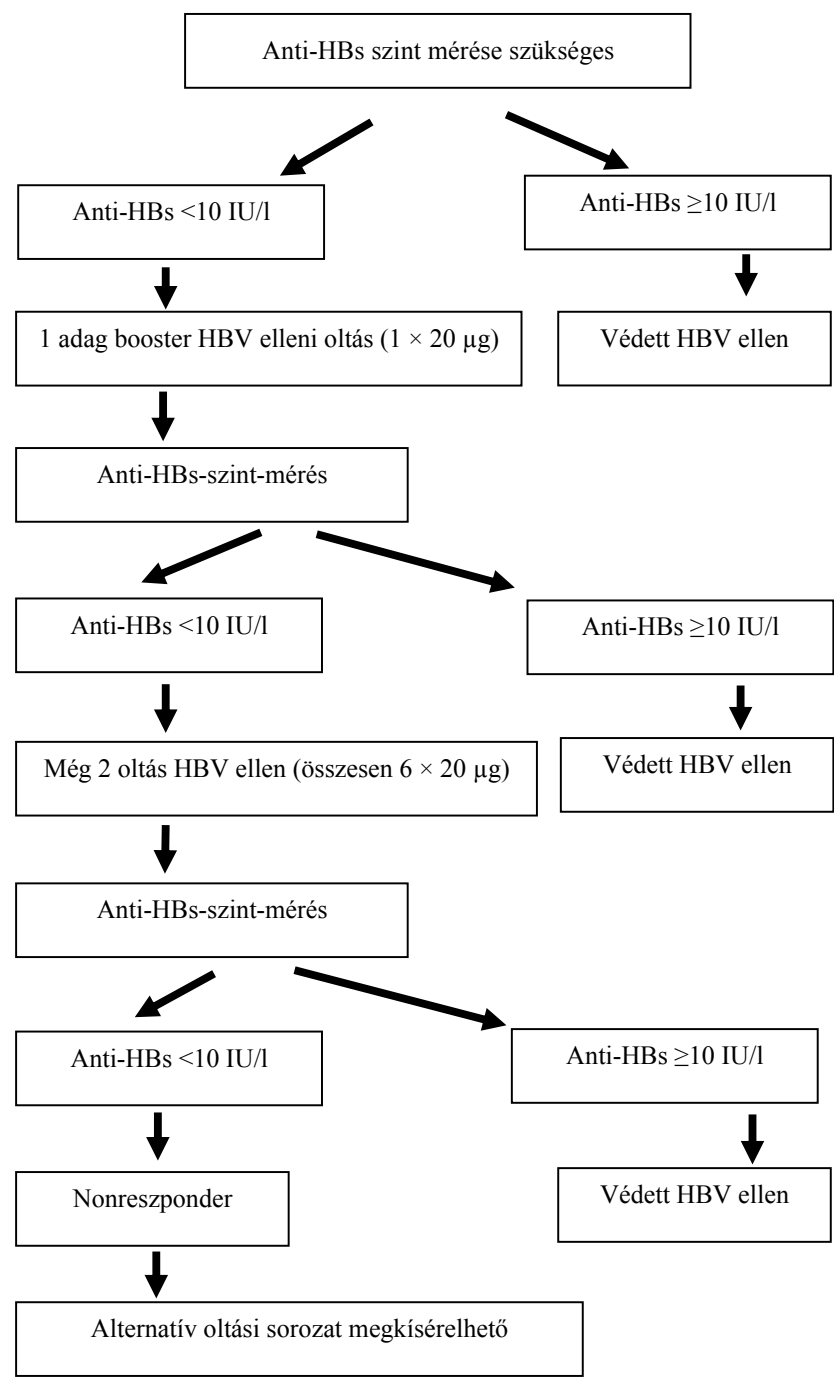

2. ábra Korábban szabályos oltási sorral oltott $(3 \times 20 \mu \mathrm{g})$ egészségügyi dolgozóra vonatkozó oltási javaslat, amennyiben nem történt anti-HBs-ellenőrzés 
HBV-védőoltásra „ál” nonreszponderek (2. ábra) Ha egy korábban (évekkel megelőzően) oltott, ép immunrendszerű személynél a munkába/oktatási intézménybe belépéskor az anti-HBs-titer negatív (<10 IU/1), emellett a HBsAg és az anti-HBcIgG szintén negatív, booster (teszt-) oltásban kell részesíteni. Ezt követően 1-2 hónap múlva a védettséget (anti-HBs) ellenőrizni kell. Ha az anti-HBs pozitív lett (>10 IU/1), akkor az egyén védett $[18,19]$. (Védett is volt a booster oltást megelőzően is, a védőoltással ellenőriztük, hogy korábbi immunizáció nyomán immunmemóriája van, „ál” nonreszponder volt.) Az „ál” nonreszponder tehát a csökkenő, majd a kimutathatóság alattivá csökkenő anti-HBstiter miatt tünik elsőre védtelennek a HBV-fertőzéssel szemben (ld. a HBV elleni védőoltás immunológiai háttere).

\section{A HBV-védőoltás tekintetében valódi nonreszponderek (2. ábra)}

Ha egy korábban (évekkel megelőzően) oltott, ép immunrendszerû személynél a munkába/oktatási intézménybe belépéskor az anti-HBs-titer negatív (<10 IU/1), emellett a HBsAg és az anti-HBcIgG szintén negatív, és booster (teszt-) oltást követően is negatív az anti-HBs-titer, akkor az egyén valószínúleg az eredeti védőoltási sor után sem lett védett. Ez esetben még két további oltást adhatunk, hogy teljes legyen a második oltási sor (a boosterrel együtt így megkapta a 3 oltásból álló sorozatot). Ha az utolsó oltás után 1-2 hónappal ellenőrizve az anti-HBs még mindig negatív (<10 IU/1), akkor az egyén valódi nonreszponder $[18,19]$. Ebben az esetben alternatív oltási sémával kell megpróbálni védetté tenni.

\section{Lehetőségek nonreszponder egyének esetén - alternatív oltási sémák}

A felnőttek 5-10\%-a nonreszponder HBV-védőoltást követően. Nonreszponderállapotra hajlamosító rizikófaktorok: férfinem, dohányzás, elhízás, életkor (>40 év), krónikus megbetegedések, veseelégtelenség, cukorbetegség, coeliakia, genetikai faktorok, immunszuppreszszió, immunmoduláció, intraglutealisan adott oltás. A HBV-fertőzésre fogékony, HBV elleni két védőoltási sor után (összesen 6 db $20 \mu \mathrm{g}$-os oltás) valódi nonreszponder egyéneket (HBsAg, $\mathrm{HBcIgG}$, anti-HBs negatív) coeliakia irányában végzett szürés és egyéb hajlamosító állapotok vizsgálata után (például krónikus veseelégtelenség stb.) alternatív oltási sorral lehet megpróbálni védetté tenni $[13,15,16,22]$ :

- dupla dózisú védőoltás intramuscularisan $(3 \times 40 \mu \mathrm{g})$; 0-1-2 hónap;

- intradermálisan $(3 \times 5 \mu \mathrm{g})$ vagy szubkután $(3 \times 20 \mu \mathrm{g}$ vagy $40 \mu \mathrm{g}) ; 0-1-2$ hónap;

- kombinált HBV- és HAV-antigént tartalmazó oltóanyag; 0-1-6 hónap.

\section{Nonreszponder egészségügyi dolgozó}

A nonreszponder egészségügyi dolgozó munkakörétől való eltiltására nincs jogszabály. A munkavállalót tájékoztatni kell, hogy nem védett HBV-fertőzéssel szemben. Posztexpozíciós profilaxisként nonreszpondereknél csak passzív immunizáció alkalmazandó. A nonreszponder egészségügyi dolgozót rendszeresen ellenőrizni kell, hogy nem lett-e HBV-fertőzött [18].

\section{A védettség ellenőrzése}

Az eddigi adatok alapján az oltási sor után kialakult seroconversiót követően a HBV-fertőzés elleni védettség becsült ideje legalább 30 év ép immunitásúakban. Azok az immunkompetens egyének, akik teljes oltási sort követően reszponderek, és késóbb az anti-HBs-szintjük <10 IU/1 lesz, védettek maradnak. Az anti-HBs-titer a védőoltás beadásának idejétől távolodva folyamatosan csökken, majd eltűnik, azonban ép immunitásúak az ellenanyag eltünése ellenére is védettek maradnak az immunmemóriának köszönhetően. Így immunkompetenseknél a seroconversio dokumentálása után szükségtelen a késóbbiekben az anti-HBs-t ellenőrizni, nem kell a lecsökkent ellenanyag-mennyiséget boosterelni. Különböző okból immunsérült egyének esetén - mivel az immunrendszer különböző komponensei nem épek felmerül az anti-HBs-titer > 10 IU/1 felett tartása, booster oltás adása (ld. immunológiai háttér) [5].

\section{Posztexpoziciós profilaxis $[5,18,19]$}

Teendők egészségügyi dolgozó potenciálisan HBV-vel fertőzött személy vérével vagy testváladékával történő expozíciója esetén.

Egészségügyi dolgozó vérrel, testváladékokkal terjedő fertőző betegségekkel, munkavégzés során történt szignifikáns expozíciója jelentendő. Minden egészségügyi intézménynek ki kell jelölni személyeket (klinikai dolgozókat), akik a posztexpozíciós profilaxis kivitelezéséért felelősek, akik expozíció esetén minden nap, a nap 24 órájában elérhetők.

A posztexpozíciós profilaxishoz használt hepatitis Bimmunglobulinnal (HBIG) kész anti-HBs-ellenanyagot adunk, ezáltal passzív védelmet biztosítva az expozíciót követően. A HBIG hatása átmeneti, 3-6 hónapig tart. A HBIG-t humán plazmából állítják elő, és nagy mennyiségú anti-HBs-t tartalmaz [18]. A Magyarországon forgalomban lévő immunglobulin-készítmények a Hepatect (Biotest - intravénás) és az Umanbig (Kedrion - intramuscularis).

Megjegyzés: A posztexpozíciós profilaxis eljárásrendjénél az Egyesült Államokban meglévő [5, 18] és az európai ajánlásokat vettük alapul, azonban a HBIG használatánál elsősorban az amerikait adaptáltuk [19]. 
HBV ellen immunizált egészségügyi dolgozó ÉS anti-HBs-titer-pozitív, > 10 IU/1 dokumentáltan egy alkalommal (ép immunitású)

Expozíciót követően HBV tekintetében teendő nincs, a dolgozó védett a HBV-vel szemben, a forrás HBsAgtesztelése is felesleges.

\section{HBV ellen immunizált egészségügyi dolgozó,} de az anti-HBs-titert nem ellenőrizték

Az egészségügyi dolgozó mielőbbi anti-HBs-titer-vizsgálata javasolt, és (ha megoldható) a forrás HBsAg-statusának ellenőrzése szükséges.

Ha a dolgozó anti-HBs-titere <10 IU/1, és a forrás HBsAg-pozitív, vagy nem ismert a forrás HBsAg-statusa, akkor a dolgozót aktív és passzív immunizációban kell részesíteni. Egy adag HBV-védőoltás mellett egy adag HBIG-készítményt kell kapnia egyszerre (ha intramuscularis, akkor két különböző helyre - a bal, illetve a jobb oldali deltaizomba), mielőbb, ha lehet 24 órán belül, de mindenképpen egy héten belül. Az aktív immunizációt szabályos oltási séma szerint kell folytatni, azaz további két oltást kell, hogy kapjon a dolgozó. Az anti-HBs-statust ezután rögzíteni kell az expozíciót követően 6-7 hónappal, a HBIG-t követően legalább 6 hónap múlva. Megjegyzés: HBIG alkalmazása után óvatosan kell interpretálni az eredményeket, mert HBIG adása után az anti-HBs még 4-6 hónappal később is kimutatható.

Ha a dolgozó anti-HBs-titere <10 IU/1, és a forrás HBsAg-negatív, akkor a sérült egy $\mathrm{HBV}$ elleni booster oltást kell, hogy kapjon, majd 1-2 hónap múlva antiHBs-titerét ellenőrizni kell. Ha ezután is negatív az antiHBs-titere, akkor újabb oltási sort kell megkísérelni, vagy alternatív oltási sémát kell megpróbálni, hogy védetté tegyük (lásd: nonreszponderek alternatív oltási sémája).

Ha a dolgozó anti-HBs-titere > $10 \mathrm{IU} / 1$, akkor a HBV tekintetében nincs szükség semmilyen posztexpozíciós profilaxisra, függetlenül a forrás HBsAg-statusától.

Amennyiben a gyors szerodiagnosztika nem kivitelezhető, akkor tekintsük úgy, hogy a dolgozó anti-HBstitere < $10 \mathrm{IU} / 1$, illetve a forrás HBsAg-pozitív [18].

\section{HBV ellen immunizált egészségügyi dolgozó, nonreszponder}

HBV ellen legalább két szabályos oltási sorral immunizált, de ismerten nonreszponder dolgozónál HBsAg-pozitív vagy ismeretlen HBV-statusú forrás esetén posztexpozíciós profilaxisként csak passzív immunizáció alkalmazandó. Egy adag HBIG-készítmény javasolt, az első adag mielőbb, ha lehet 24 órán belül, de mindenképpen egy héten belül, majd a második adag egy hónappal később. Ha nem kíséreltünk meg alternatív oltási sorokat, ezt megpróbálhatjuk, hogy a jövőben védetté tegyük HBV ellen. Amennyiben a forrás igazoltan HBsAg-negatív, akkor semmilyen posztexpozíciós készítményre nincs szükség a HBV tekintetében [18, 19].
HBV ellen nem immunizált vagy nem teljes oltási sorban részesült egészségügyi dolgozó

A korábban $\mathrm{HBV}$ elleni immunizációban nem részesült vagy nem teljes oltási sorral oltott egészségügyi dolgozót HBsAg-pozitív forrással történő expozíció esetén aktív és passzív immunizációban kell részesíteni. Egy adag HBV-védőoltás mellett egy adag HBIG-készítményt kell, hogy kapjon egyszerre (ha intramuscularis a HBIGkészítmény, akkor két különböző helyre - a bal, illetve a jobb oldali deltaizomba), mielőbb, ha lehet 24 órán belül, de mindenképpen egy héten belül. Az aktív immunizációt szabályos oltási séma szerint kell folytatni, azaz a dolgozónak további két oltást kell kapnia. Az anti-HBsstatust ezután rögzíteni kell, az utolsó védőoltás után 1-2 hónappal, azaz az expozíciót követően 6-7 hónappal, a HBIG-t követően legalább 6 hónap múlva. Megjegyzés: HBIG alkalmazása után óvatosan kell interpretálni az eredményeket, mert HBIG adása után az anti-HBs még 4-6 hónappal később is kimutatható [5, $18]$.

Várandós egészségügyi dolgozó esetén alkalmazandó posztexpozíciós profilaxis

A fentiek ugyanúgy igazak várandósság esetén is [19].

Anyagi támogatás: A közlemény megírása, illetve a kapcsolódó kutatómunka anyagi támogatásban nem részesült.

Szerzői munkamegosztás: J. Cs.: A HBV-fertőzésről és megelőzéséről általában, HBV-fertőzés elleni immunizáció, és az Egészségügyi dolgozók rizikója című fejezetek, valamint a Mi az oka a valódi nonreszponder állapotnak? címú alfejezet megírása. O. B., Sch. P.: A hepatitis B-vírus elleni védőoltás immunológiai háttere címú fejezet megírása. K. A.: Szakmai felügyelet, ellenőrzés, javítás.

Érdekeltségek: J. Cs.: Tanácsadói/előadói tiszteletdíj: GSK, Sanofi, MSD, Pfizer. K. A.: Tanácsadói/előadói tiszteletdíj: GSK, Sanofi, Pfizer. O. B.: Tanácsadói/előadói tiszteletdíj: GSK, Sanofi, Pfizer. Sch. P.: Nincsenek érdekeltségei.

\section{Irodalom}

[1] European Association for the Study of the Liver. EASL 2017 Clinical Practice Guidelines on the management of hepatitis B virus infection. J Hepatol. 2017; 67: 370-398.

[2] Hofstraat SH, Falla AM, Duffell EF, et al. Current prevalence of chronic hepatitis $\mathrm{B}$ and $\mathrm{C}$ virus infection in the general population, blood donors and pregnant women in the EU/EEA: a systematic review. Epidemiol Infect. 2017; 145: 2873-2885.

[3] Walayat S, Ahmed Z, Martin D, et al. Recent advances in vaccination of non-responders to standard dose hepatitis $B$ virus vaccine. World J Hepatol. 2015; 7 : 2503-2509.

[4] Thio CL, Hawkins Ca. Hepatitis B virus and hepatitis delta virus. In: Bennet JE, Dolin R, Blaser MJ. (eds.) Mandell, Douglas, and Bennett's principles and practice of infectious diseases. Chapter 
148. Eighth edn. Elsevier, Philadelphia, PA, 2014; Vol 2, pp. 1815-1839.e7

[5] Schillie S, Vellozzi C, Reingold A, et al. Prevention of hepatitis B virus infection in the United States: recommendations of the Advisory Committee on Immunization Practices. MMWR Recomm Rep. 2018; 67(RRI): 1-31

[6] Saco TV, Strauss AT, Ledford DK. Hepatitis B vaccine nonresponders. Possible mechanisms and solutions. Ann Allergy Asthma Immunol. 2018; 121: 320-327.

[7] World Health Organization (WHO). Hepatitis B vaccines: WHO position paper - July 2017. Weekly Epidemiological Record 2017; 92(27): 369-392.

[8] Introduction of the vaccines in Hungary, VACSATC Hungary [Védőoltások bevezetése és főbb változásai Magyarországon.] VACSATC Magyarország, Oltásbiztonság, Budapest. Available from: http://oltasbiztonsag.hu/?V\%E9d\%F5olt\%Elsok-bevezet\% E9se-\%E9s-f\%F5bb-v\%E1ltoz\%Elsai-Magyarorsz\% Elgon\&pid=121 [accessed: May 21, 2019]. [Hungarian]

[9] Maupas PA, Simon DF. Immunization against hepatitis B. Lancet $1988 ; 2: 875-876$.

[10] Immunization of health-care personnel, recommendations of the Advisory Committee on Immunization Practices (ACIP). MMWR Recomm Rep. 2011; 60(RR7): 1-45.

[11] Siegrist CA. Vaccine immunology. In: Plotkin S, Orenstein W, Offit P, et al. Plotkin's vaccines. 7th edn. Elsevier, Philadelphia, PA, 2017.

[12] Vitaliti G, Praticò AD, Cimino C, et al. Hepatitis B vaccine in celiac disease: yesterday, today and tomorrow. World J Gastroenterol. 2013; 19: 838-845.

[13] Yang S, Tian G, Cui Y, et al. Factors influencing immunologic response to hepatitis B vaccine in adults. Sci Rep. 2016; 6: 27251.

[14] Tajiri K, Shimizu Y. Unsolved problems and future perspectives of hepatitis B virus vaccination. World J Gastroenterol. 2015; 21: 7074-7083
[15] Filippelli M, Lionetti E, Gennaro A, et al. Hepatitis B vaccine by intradermal route in non responder patients: an update. World $\mathrm{J}$ Gastroenterol. 2014; 20: 10383-10394.

[16] Nicolas JF, Guy B. Intradermal, epidermal and transcutaneous vaccination: from immunology to clinical practice. Expert Rev Vaccines 2008; 7: 1201-1214.

[17] Hepatitis B Vaccine (Recombinant), Adjuvanted. HEPLISAV-B. Available from: https://www.fda.gov/biologicsbloodvaccines/ vaccines/approvedproducts/ucm584752.htm

[18] Schillie S, Murphy TV, Sawyer M, et al. CDC guidance for evaluating health-care personnel for hepatitis B virus protection and for administering postexposure management. MMWR Recomm Rep. 2013; 62(RR10): 1-19.

[19] Puro V, De Carli G, Cicalini S, et al. European recommendations for the management of healthcare workers occupationally exposed to hepatitis virus and hepatitis C virus. Euro Surveill. 2005; 10: 260-264.

[20] Percutan injuries in the health care settings. [Percutan sérülések az egészségügyi ellátásban.] Epinfo 2003; 1: 3-6. [Hungarian]

[21] Methodology letter of the National Public Health and Medical Officer Service about vaccines in 2019. [A Nemzeti Népegészségügyi Központ módszertani levele a 2019. évi védőoltásokról.] Available from: https://www.antsz.hu/felso_menu/temaink/ jarvany/modszertani_levelek/VML_2019.html. [Hungarian]

[22] Carpenter SL, Soucie JM, Presley RJ, et al. Hepatitis B vaccination is effective by subcutaneous route in children with bleeding disorders: a universal data collection database analysis. Haemophilia 2015; 21: e39-e43.

(Jekkel Csilla dr., Budapest, Albert Flórián út 5-7., 1097 e-mail: jekkel.csilla@dpckorhaz.hu)

\title{
MEGHÍ Vó
}

\author{
Az Észak-Közép-budai Centrum, Új Szent János Kórház Tudományos Bizottsága \\ tisztelettel meghívja az érdeklődőket a következő tudományos ülésére.
}

Időpont: 2019. október 24. (csütörtök) 14 óra

\begin{abstract}
Helyszín: Szent János Kórház Auditóriuma - 1125 Budapest, Diós árok 1-3.
\end{abstract}
Téma: „Kapcsolódási pontok az akut töréskezelés és a késői rekonstrukciós beavatkozások között”

Üléselnök: Prof. Dr. Jánosi András

\section{Program:}

Dr. Kiss Jenő: 100 éves az Ortopéd-Traumatológiai Osztály

10 perc

Dr. Tibay György: Periprotetikus törések és protézislazulások ellátása Wágner-szárral

10 perc

Dr. Juhász András: Nyílt darabos törések ellátása - módszerváltásos esetek bemutatása

15 perc

Dr. Antal János: Könyökprotézis beültetése darabos könyöktáji törések valamint

post-traumás funkciózavarok ellátására

15 perc

\section{Minden érdeklődőt szeretettel várunk!}

